\title{
IDENTIFIKASI FRAGMEN HV1 DNA MITOKONDRIA INDIVIDU DATARAN RENDAH DAN DATARAN TINGGI
}

\author{
${ }^{1}$ Rina Budi Satiyarti, ${ }^{2}$ Siti Aminah, ${ }^{3}$ Tina Dewi Rosahdi \\ ${ }^{1}$ UIN Raden Intan Lampung. Jalan Letkol H. Endro Suratmin Bandar Lampung \\ ${ }^{2}$ UIN Sunan Gunung Jati Bandung. Jalan A.H. Nasution No. 105 Kota Bandung \\ email: rinabudi07@gmail.com
}

\begin{abstract}
An individual adaptation towards the geographical altitude associated with genetic factors, one of the genetic materials of the most widely used to study the characteristic of individuals in the population is the mitochondrial DNA.Based on that condition, this research will deciding human Fragmen HVI mtDNA from Indramayu as lowland individual and Sukabumi as highland individual. The purpose of this research is to identify hair root and the epithelial cell of the mouth as a source DNA mitochondrial that can used for a amplification of human fragment DNA mitokondria template and to identify fragment territory HVI mtDNA by using Polimerase Chain Reaction (PCR) technic and detecting the yield of PCR from lowland and highland individual. The steps include the lysis to do the sample of the hair root and the epithelial cell of the mouth, amplified HV1 fragment mtDNA to utilize Polimerase Chain Reaction (PCR) technique and the result of PCR with elektroforesis gel agarosa. This research has been successfully, hair root and the epithelial cell can do analyze DNA mitochondrial marked by the fragment measuring $0,4 \mathrm{~kb}$ in the area D-Loop mtDNA and it can easier amplification is hair root characterized by the presence of DNA bands in agarose gel electrophoresis.
\end{abstract}

Keywords: mtDNA, HV1, PCR, lowland, highland, D-loop.

\section{PENDAHULUAN}

Di dalam tubuh manusia terdapat suatu sistem kesetimbangan yang berperan dalam menjaga fungsi fisiologis tubuh untuk beradaptasi terhadap lingkungannya. Proses adaptasi yang dilakukan oleh tubuh manusia salah satunya adalah beradaptasi terhadap ketinggian geografis. Faktor ketinggian geografis biasanya dihubungkan dengan kadar oksigen. Udara kering mengandung 20,93 \% oksigen pada semua ketinggian dengan tekanan rata-rata barometrik $760 \mathrm{mmHg}$, ketika ketinggian bertambah kadar oksigen tetap sama namun jumlah partikel oksigen mengalami pengurangan yang signifikan akibat turunnya tekanan barometrik. Daerah dataran rendah diketahui memiliki jumlah oksigen yang relatif lebih banyak jika dibandingkan dengan dataran tinggi.Hasil dari adaptasi tersebut memungkinkan terjadinya perubahan 
fisiologis dalam hal respirasi, sirkulasi, dan jumlah sel darah merah dalam tubuh.Orang yang tinggal di daerah dataran tinggi memiliki asupan jumlah $\mathrm{O}_{2}$ lebih sedikit sehingga mengakibatkan oksigen ke seluruh jaringan menjadi berkurang ${ }^{[1]}$.

Oksigen sangat diperlukan untuk memproduksi energi, jika seseorang kekurangan energi di dalam tubuhnya maka seluruh proses yang berlangsung di dalam tubuh akan terganggu, sehingga tubuh akan beradaptasi dengan cara meningkatkan produksi sel darah merah dan konsentrasi hemoglobin. Sel darah merah berfungsi untuk mengikat oksigen. Semakin tinggi jumlah sel darah merah dan konsentrasi hemoglobin maka kapasitas oksigen respirasi akan meningkat ${ }^{[1]}$. Perbedaan kadar $\mathrm{O}_{2}$ antara dataran tinggi dan dataran rendah akan mengakibatkan perbedaan laju metabolisme tubuh.

Mishmar et,al., (2003) menemukan indikasi kuat bahwa seleksi alam khususnya faktor geografi, iklim dan nutrisi memiliki peran penting dalam membentuk variasi profil DNA mitokondria. Mitokondria adalah organel yang terletak di dalam sitoplasma sel eukariota.Struktur sel eukariota ini berupa kantung yang diselaputi oleh dua membran yaitu membran luar dan membran dalam. Membran dalam membentuk struktur yang melipat ke dalam disebut krista dan memiliki dua kompartemen yaitu matriks dan ruang antar membran. Membran luar mengandung sejumlah protein transport dan enzim-enzim yang terlibat dalam biosintesis lipid dan metabolisme mitokondria. Membran dalam memiliki struktur melekuk dan melipat ke bagian matriks mitokondria, yang dikenal sebagai krista. Struktur melekuk ini sangat membantu dalam meningkatkan luas permukaan membran dalam sehingga meningkatkan kemampuannya dalam menghasilkan ATP. Membran dalam dan matriks mitokondria terkait erat dengan aktivitas utama mitokondria yaitu terlibat dalam pembentukan energi, oksidasi asam lemak dan siklus krebs. Matriks mitokondria mengandung protein, enzim, ribosom dan DNA mitokondria.

DNA mitokondria manusia memiliki sejumlah sifat genetik khas yang dibedakan dari genom inti, diantaranya adalah memiliki laju mutasi yang lebih tinggi yaitu sekitar 10-17 kali DNA inti.DNA mitokondria terdapat lebih dari 1000 kopi dalam tiap sel, sedangkan DNA inti hanya berjumlah 2 kopi.DNA inti merupakan hasil rekombinasi DNA kedua orang tua sedangkan DNA mitokondria hanya diwariskan dari ibu.DNA mitokondria memiliki daerah pengkode dan daerah non pengkode.DNA mitokondria mengandung 37 gen pengkode untuk rRNA, 22 tRNA, dan 13 polipeptida yang 
merupakan subunit kompleks enzim yang terlibat dalam fosforilasi oksidatif.Daerah yang tidak mengkode yaitu D-Loop. D-Loop memiliki dua daerah yaitu Hipervariabel 1 (HV1) dan hipervariabel 2 (HV2).

Daerah Hipervariabel 1 (HV1) bersifat sangat variatif (mempunyai urutan basa nukleotida yang bervariasi) dan mempunyai laju evolusi lima kali lebih cepat dibandingkan dengan daerah lain dalam genom mitokondria. Keunikan daerah HV1 adalah memiliki tingkat polimorfisme (substitusi basa) yang tinggi dalam DNA Mitokondria (mtDNA). Daerah ini sangat beragam antara individu tetapi sama untuk kerabat yang satu garis keturunan ibu.

Penelitian tentang adaptasi genetik manusia belum banyak dilakukan, terutama penelitian yang menghubungkan ketinggian geografis dengan DNA manusia pada dataran rendah dan dataran tinggi di Indonesia. Gelvi, dkk., (2004) meneliti tentang adaptasi ketinggian pada dataran tinggi Tibet, yaitu bagaimana protein menjaga enzim yang berperan dalam perlindungan otot terhadap adanya bahaya oksidatif. Penelitian tersebut menganalisis adaptasi genetik manusia pada ketinggian yang sangat ekstrim yaitu kurang dari $5500 \mathrm{~m}$. Daerah kajian penelitian tersebut terletak pada tingkat DNA inti dan protein.

Berdasarkan latar belakang di atas, maka dalam penelitian ini akan dilakukan penentuan fragmen HV1 DNA mitokondria manusia pada individu dataran rendah provinsi Jawa Barat. Hasil penelitian diharapkan dapat memberikan informasi mengenai fragmen HV1 DNA mitokondria manusia. Selain itu, data yang didapatkan akan digunakan dalam penyusunan database DNA mitokondria pada populasi manusia Indonesia.

\section{METODE PENELITIAN}

Metode penelitian yang digunakan adalah metode penelitian eksperimental yang terdiri dari empat tahapan, yaitu pengumpulan sampel, lisis terhadap sampel DNA mitokondria yang telah diperoleh dengan menggunakan buffer lisis, amplifikasi daerah HV1 DNA mitokondria sampel dengan menggunakan metode PCR, pendeteksian hasil PCR dengan elektroforesis gel agarosa. 


\section{HASIL DAN PEMBAHASAN}

\section{Karakteristik Sampel}

Tahapan awal dalam penelitian ini adalah pengambilan sampel akar rambut dan sel epitel mulut dari individu dataran rendah Indramayu dan dataran tinggi Sukabumi. Sampel yang diambil dari kedua individu berupa akar rambut dan sel epitel mulut. Akar rambut dikelilingi oleh folikel.Folikel merupakan pusat tumbuh rambut yang mengandung keratin yang berasal dari epitel epidermis, sehingga terdapat lebih banyak DNA mitokondria dibandingkan dengan bagian pangkalnya.

\section{Hasil Lisis Sampel dengan Menggunakan Buffer lisis}

Pengambilan sampel dari sel akar rambut dilakukan dengan cara mencabut 5-10 helai rambut sampai bagian akarnya dan pengambilan sampel sel epitel mulut dengan cara berkumur. Perlakuan sampel sel akar rambut dan sel epitel mulut selanjutnya dilakukan dengan buffer lisis untuk mendapatkan DNA mitokondria. Prinsip buffer lisis adalah perusakan dinding sel tanpa harus merusak DNA yang diinginkan, sedangkan tujuan dari lisis sel yaitu untuk memecah dinding sel dan mengeluarkan seluruh isi sel termasuk DNA. Pada proses lisis sampel diperoleh fragmen DNA mitokondria yang digunakan sebagai templat.

Dalam tahap lisis dilakukan inkubasi pada suhu $55^{\circ} \mathrm{C}$ selama 1 jam. Inkubasi ini berperan dalam mengoptimalkan kerja enzim proteinase-K yaitu untuk mendegradasi enzim-enzim DNAse dan protein lainnya untuk menghindari degradasi DNA terutama DNA mitokondria pada larutan sampel. Protein dalam DNA mitokondria dideaktifasi dengan pemanasan pada suhu $95^{\circ} \mathrm{C}$ agar tidak merusak molekul-molekul proteinnya dan waktu pemanasan selama 10 menit sehingga didapatkan ekstrak DNA mitokondria yang berada dalam supernatan dan dapat langsung digunakan sebagai templat untuk amplifikasi. Templat DNA mitokondria yang diperoleh dipisahkan ke dalam tabung mikro yang baru untuk menghindari bercampurnya kembali DNA dengan molekul lainnya. Untuk menjaga kondisi fisiologis mtDNA, templat disimpan dalam freezer pada suhu $-20^{\circ} \mathrm{C}$. Sampel yang terdapat pita DNA dari hasil penelitian dapat dilihat pada Tabel 1. 
Tabel 1. Sampel yang digunakan untuk lisis sel dengan menggunakan buffer lisis

\begin{tabular}{ccc}
\hline Lisis sel & Sampel & Hasil \\
\hline Buffer lisis & Akar rambut & Menunjukkan pita DNA \\
Buffer lisis & Epitel mulut & Tidak menunjukkan pita \\
& & DNA \\
\hline
\end{tabular}

Pada Tabel 1. Sampel akar rambut dengan menggunakan buffer lisis menunjukkan pita DNA, sedangkan pada sampel epitel mulut tidak menunjukkan pita DNA. Karena sel yang ada pada akar rambut tidak terlalu banyak dan memiliki aktifitas metabolik yang sangat tinggi sehingga pada bagian akar rambut terdapat sejumlah besar mitokondria, sedangkan pada sel epitel mulut yang diperoleh dengan cara berkumur merupakan campuran yang sangat kompleks dan terdapat pula sisa makanan. Keberadaan zat-zat tersebut dalam sampel epitel mulut mengganggu reaksi PCR, terbukti dengan tidak terdapatnya pita DNA pada penelitian ini.

\section{Hasil Amplifikasi Fragmen HV1 mtDNA dengan metode PCR}

PCR merupakan suatu metode sintesis DNA secara in vitro untuk memperbanyak fragmen DNA yang spesifik. Metode ini melibatkan dua oligonukleotida sebagai primer yang membatasi fragmen DNA mitokondria yang akan diperbanyak (amplifikasi) dan menginisiasi proses perbanyakan. Produk PCR berupa amplikon fragmen D-loop DNA mitokondria, yang kemudian dikonfirmasi keberadaannya melalui elektroforesis gel agarosa. Keberhasilan amplifikasi diidentifikasi dengan cara membandingkan posisi fragmen sampel dengan marker DNA yang sudah diketahui ukurannya dan untuk meyakinkan bahwa DNA mitokondria yang diamplifikasi merupakan DNA mitokondria target bukan DNA asing.

Siklus PCR pada penelitian ini meliputi tiga tahap yaitu tahap denaturasi, tahap penempelan (Annealing) dan tahap pemanjangan (Extension). Tahap denaturasi bertujuan untuk melepaskan semua ikatan hidrogen yang menghubungkan dua untai DNA sehingga menghasilkan DNA tunggal. Suhu denaturasi DNA templat berkisar antara $93^{\circ} \mathrm{C}-95^{\circ} \mathrm{C}$, tergantung pada panjang fragmen pada DNA target. Pada tahap penempelan (annealing) suhu dan waktu yang digunakan yaitu $50^{\circ} \mathrm{C}$ selama 1 menit, 
pemilihan suhu dan waktu annealing berkaitan dengan panjang primer yang digunakan pada proses PCR, sedangkan pada tahap pemanjangan (extension) suhu dan waktu yang digunakan yaitu $72^{\circ} \mathrm{C}$ selama 4 menit. Proses ekstensi primer pada proses PCR dilakukan pada suhu $72^{\circ} \mathrm{C}$ karena pada suhu tersebut merupakan suhu optimum DNA polimerase yang biasa digunakan untuk proses PCR.

Setiap melakukan reaksi PCR dibutuhkan reagen-reagen PCR dan keberhasilan PCR ditentukan dari komposisi reagen-reagen tersebut. Campuran dari semua reagen PCR yang dibutuhkan dalam setiap kali reaksi PCR disebut master mix . Reagen PCR yang digunakan diantaranya buffer PCR, $\mathrm{MgCl}_{2}$, dNTP, primer M1, primer M2, DNA polimerase dan $\mathrm{ddH}_{2} \mathrm{O}$.

dNTP bertindak sebagai building block DNA yang diperlukan dalam proses ekstensi DNA. dNTP akan menempel pada gugus hidroksi (-OH) pada ujung 3' dari primer membentuk untai baru yang komplementer dengan untai DNA templat. Bufer PCR untuk menjamin $\mathrm{pH}$ medium, selain bufer PCR diperlukan juga adanya ion $\mathrm{Mg}^{2+}$ yang berasal dari $\mathrm{MgCl}_{2} . \mathrm{MgCl}_{2}$ bertindak sebagai kofaktor yang berfungsi menstimulasi aktivitas DNA polimerase. $\mathrm{MgCl}_{2}$ akan meningkatkan interaksi primer dengan templat yang membentuk kompleks larut dengan dNTP (senyawa antara). DNA taq polimerase dalam proses PCR berfungsi sebagai katalis untuk reaksi polimerisasi DNA. Enzim ini diperlukan untuk tahap ekstensi DNA ${ }^{[21]}$.

Untuk mendapatkan fragmen hasil amplifikasi yang diinginkan, maka komponen PCR harus dipastikan sudah berada dalam campuran atau master mix. Masing-masing komponen memiliki komposisi tertentu dalam setiap campuran dan komposisi templat juga harus sesuai agar hasil amplifikasi yang diperoleh optimal, dibutuhkan optimasi terhadap masing-masing komponen PCR.

Komponen penting lain yang juga berbeda dalam reaksi PCR adalah penggunaan primer. Keberhasilan suatu proses PCR sangat tergantung dari primer yang digunakan. Di dalam proses PCR, primer berfungsi sebagai pembatas fragmen DNA target yang akan diamplifikasi dan sekaligus menyediakan gugus hidroksi (-OH) pada ujung 3' yang diperlukan untuk proses eksitensi DNA. Perancangan primer dapat dilakukan berdasarkan urutan DNA yang telah diketahui ataupun dari urutan protein yang dituju.Data urutan DNA atau protein bisa didapatkan dari database genebank. Apabila urutan DNA maupun urutan protein yang dituju belum diketahui maka perancangan 
primer dapat didasarkan pada hasil analisis homologi dari urutan DNA atau protein yang telah diketahui mempunyai hubungan kekerabatan yang terdekat ${ }^{[17]}$.

\section{Rancangan Primer}

Rancangan primer dibuat dengan cara memasukan urutan D-Loop mtDNA yang diperoleh dari database NCBI ke dalam program seqman DNA star, lalu urutan primer yang kita gunakan dimasukkan ke dalam program seqman tersebut. Tujuan dari proses ini adalah untuk mengetahui apakah primer yang digunakan merupakan primer spesifik dan urutan nukleotidanya menempel pada urutan D-Loop mtDNA. Gambar 1. merupakan rancangan primer M1 menggunakan program seqman DNA star.

\begin{tabular}{|c|c|}
\hline \multirow[t]{2}{*}{ Selection: $15928 \rightarrow 15947=20$} & $16.519 \mathrm{~kb}$ \\
\hline & $15970 \quad 15980$ \\
\hline Translate & CTCCACCATTAGCACCCAAAGCTAAGATTCTAATTTAAACTATTCTCTGTTCTTTCAT \\
\hline $\begin{array}{l}\text { mitokondria genom.SEQ }(1>16519) \rightarrow \\
\text { M1.txt }(1>20) \quad \rightarrow\end{array}$ & $\begin{array}{l}\text { CTCCACCATTAGCACCCAAAGCTAAGATTCTAATTAAAACTATTCTCTGTTCTTTCAT } \\
\text { ICACCATTAGCACCCAAAGCT }\end{array}$ \\
\hline
\end{tabular}

Gambar 1.Rancangan primer M1 menggunakan program seqman DNA star

Pada Gambar 1. primer M1 menempel pada urutan D-Loop mtDNA dengan urutan nukleotida -CACCATTAGCACCCAAAGCT- pada posisi 15.928-15.947 yaitu menunjukkan bahwa primer yang digunakan spesifik. Gambar 2 berikut ini merupakan rancangan primer M2 menggunakan program seqman DNAstar.

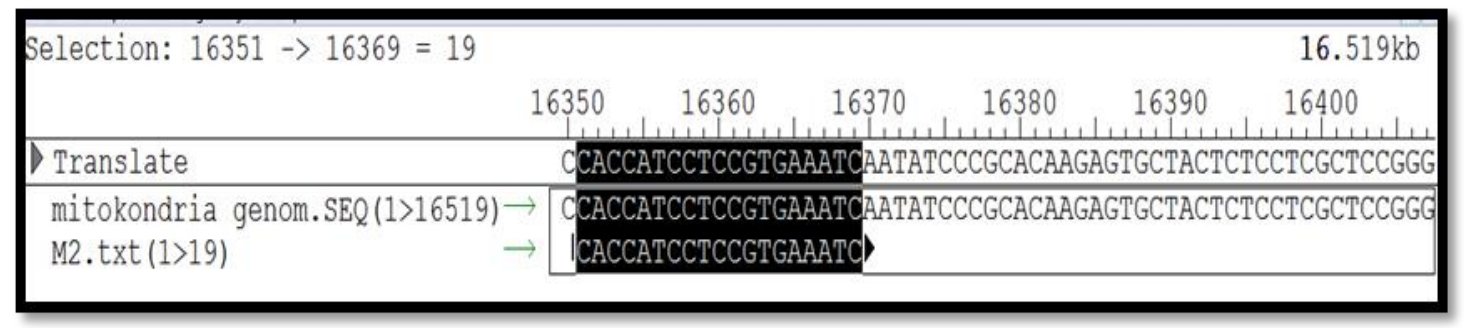

Gambar 2.Rancangan primer M2 menggunakan program seqman DNA star

Pada Gambar 2 primer M2, primer M2 menempel pada urutan D-Loop mtDNA dengan urutan nukleotida -CACCATCCTCCGTGAAATC- sebagai komplemen dari primer M2 yang digunakan yaitu -GTGGTAGGAGGCACTTTAG- menempel pada posisi $16.351-16.369$. 




Gambar 3. Ukuran fragmen hasil PCR

Gambar 3 menunjukkan proses amplifikasi dengan metode PCR pada sampel akar rambut dengan menggunakan primer M1 dan M2 memberikan hasil amplifikasi fragmen yang berukuran sekitar $0,4 \mathrm{~kb}$ atau $403 \mathrm{pb}$. Cara menentukan ukuran fragmen yaitu berdasarkan informasi database genom mitokondria yang didapatkan dari NCBI melalui internet, kemudian dilakukan proses penempelan primer dengan menggunakan program DNA star. Urutan genom mitokondria, primer M1 dan primer M2 dimasukkan dalam program DNA star tersebut, setelah itu primer M1 dan primer M2 akan menempel pada daerah yang diinginkan.

\section{Amplikon Fragmen Daerah HV1 mtDNA Hasil PCR}

Produk PCR berupa amplikon fragmen HV1 mtDNA kemudian dikonfirmasi keberadaannya melalui elektroforesis gel agarosa. Gel agarosa terbuat dari agarosa yang merupakan polisakarida rumput laut dan akan membentuk gel ketika dilarutkan dengan buffer TAE melalui pemanasan. EtBr (Ethidium Bromide) yang ditambahkan pada gel mempunyai kemampuan untuk menyisip di antara pasangan basa nukleotida dalam untai DNA mitokondria karena memiliki geometri molekul yang hampir sama dengan DNA mitokondria yaitu planar. Hal ini menunjukkan bahwa jumlah molekul EtBr sebanding dengan jumlah pasangan basa nukleotida DNA mitokondria yang diamati. EtBr berfungsi sebagai pewarna DNA yang akan menyisip di sela-sela basa nukleotida.

Pengamatan hasil elektroforesis dilakukan di bawah sinar ultraviolet (UV) pada panjang gelombang $260 \mathrm{~nm}$.EtBr dapat berflouresensi bila disinari $U V$, dengan warna merah orange.Pada $\mathrm{pH}$ mendekati netral, DNA mitokondria bermuatan negatif sehingga 
molekul ini dapat bermigrasi dari kutub negatif (anoda) ke kutub positif (katoda) dengan kecepatan yang dipengaruhi oleh berat molekul fragmen DNA mitokondria dan kekuatan arus listrik yang digunakan. Fragmen DNA mitokondria yang memiliki berat molekul yang rendah akan bergerak lebih cepat daripada yang memiliki berat molekul yang besar.

Untuk menentukan ukuran hasil PCR digunakan penanda (marker), yang berfungsi sebagai penanda bahwa fragmen yang diinginkan berhasil diamplifikasi. Pita untuk fragmen HV1 menggunakan primer M1 dan M2 berukuran sekitar 0,4 kb. Untuk mengetahui apakah pita DNA hasil elektroforesis sesuai dengan target penelitian maka harus dilakukan elektroforesis bersama-sama dengan DNA standar yang telah diketahui ukurannya ${ }^{[23]}$. Ukuran $0,4 \mathrm{~kb}$ dapat dilihat dengan membandingkan posisi pita dengan marker yang digunakan yaitu KAPA 1 KB DNA ladder. Hasil elektroforesis sampel akar rambut dengan menggunakan buffer lisis yang telah divisualisasi dengan lampu UV dapat dilihat pada Gambar 4.

Gambar 4.4 menujukkan M adalah penanda (marker) KAPA 1 KB DNA ladder dengan ukuran pitanya disamping kanan 0,5 kb sedangkan angka 1 menunjukkan kode sampel dataran rendah dan angka 2 menunjukkan kode sampel dataran tinggi. Pita berukuran 0,4 kb menandakan adanya fragmen HV1 mtDNA.

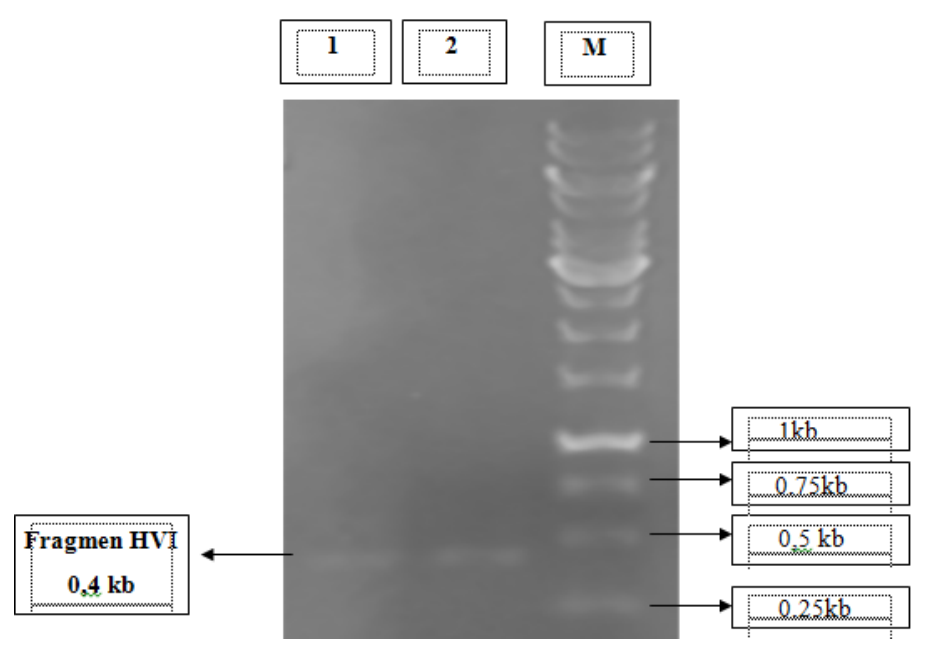

Gambar 4. Elektroforesis gel agarosa hasil amplifikasi fragmen HV1 mtDNA. 
Hasil elektroforesis gel agarosa pada sampel sel epitel mulut dengan menggunakan buffer lisis dapat dilihat pada Gambar 5.
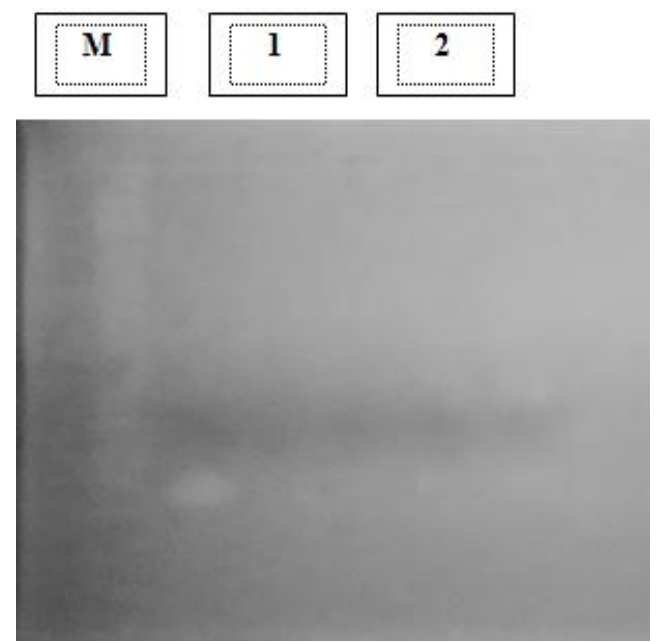

Gambar 5. Elektroforesis gel agarosa hasil amplifikasi fragmen HV1 dari sel epitel mulut menggunakan buffer lisis.

Hasil elektroforesis gel agarosa pada sampel sel epitel mulut dengan menggunakan buffer lisis tidak menunjukkan pita DNA karena sampel epitel mulut yang diperoleh dengan cara berkumur di dalamnya terdapat sisa makanan. Keberadaan sisa makanan dalam sampel mengganggu pada reaksi PCR sedangkan pada akar rambut lebih mudah dilisis karena akar rambut dikelilingi oleh folikel yang yang mengandung keratin dari epitel epidermis, sehingga terdapat lebih banyak DNA mitokondria.

Pada penelitian ini dilakukan proses sekuensing, akan tetapi belum bisa dilakukan analisis lebih lanjut karena hasil sekuensing yang didapatkan kurang baik sehingga tidak bisa dipastikan terjadi mutasi atau tidak terjadi mutasi pada individu dataran rendah maupun dataran tinggi. Tampilan sekuensing individu dataran rendah dengan menggunakan primer M1 disajikan pada Gambar 6. 


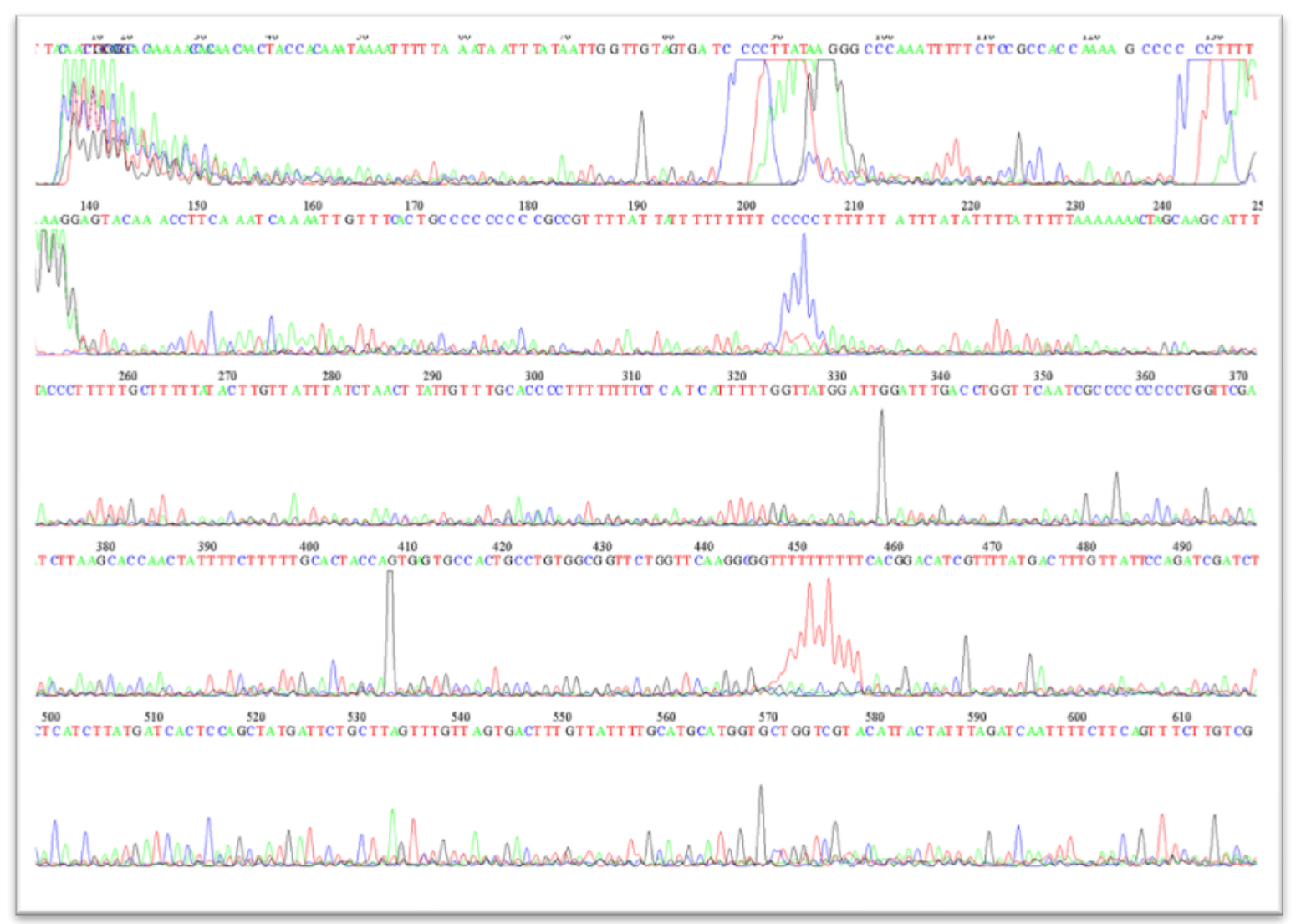

Gambar 6. Tampilan sekuensing individu

\section{SIMPULAN DAN SARAN}

Dari hasil penelitian ini dapat ditarik kesimpulan sebagai berikut :

1. Sel epitel mulut dan akar rambut dapat dilakukan analisis DNA mitokondria, ditandai dengan terdapatnya pita DNA pada elektroforesis gel agarosa.

2. Berdasarkan hasil penelitian yang dilakukan, penggunaan metode PCR dengan menggunakan primer M1 dan M2 menghasilkan fragmen DNA berukuran 0,4 kb pada elektroforesis gel agarosa.

\section{DAFTAR PUSTAKA}

Gumilar, G.G, Supriyanti, F. M.T., Siti, H.H. (2008). Bioteknologi. Bandung : Jurusan Pendidikan Kimia FPMIPA UPI.

Devor, E.J.(2005). IDTutorial : Mitochondrial DNA).USA : Integrated DNA Technologies.

Poedjiadji, Anna dan Supriyanti F.M.T. (2006). Dasar-dasar Biokimia. Jakarta : Universitas Indonesia Press. 
Wikipedia. 2014.http://id.wikipedia. Org/wiki/. diakses tanggal 1 November 2014, 21.30 WIB.

Gaffar, Shabrani, M.Si. 2007. Buku Ajar Bioteknologi Molekul. Bandung: FMIPA Universitas Padjajaran.

Stanfield, William D., Jaime S. Colome., Raul J. Cano. 2003. Shaum's Easy Outlines: Molecular and Cell Biology. USA : McGraw-Hill Companies, Inc.

Purves, William K., David Sadava., Gordan H.Orians., and Craig Heller. 2004. Life : The Science Of Biology. Edisi Ketujuh. United Staties of America: Sinauer Associates and W. H. Freeman.

Yuwono, Tribowo. 2009. Biology Molekular.Jakarta: Erlangga.

Anderson, S. et al. (1981). " Sequence and Organization of the Cambridge Reference Sequence for Human Mitochondrial DNA”. Nat Genet. 23, 147.

www.mitomap.org diakses pada tanggal 2 November 2014, 22.00 WIB.

Susmiarsih, T. (2010). Peran Genetik DNA Mitokondria pada Motilitas Spermatozoa. Majalah kesehatan Pharma Medika, 2010 Vol.2., No.2.

Nakada, K. (2006). Mitochondria- Related Male Infertility. PNAS: 103 (41): 151 48-53.

Giles, R.E., Blanc, H., Cann H.M., dan Wallace, D.C. 1980. “ Maternal Inheritance of Human Mitochondrial DNA “. Proc. Natl. Acad. SCI . USA. 77, (11), 67156719.

Wallace, D.C., 1992: Diseases of the mitochondrial DNA, Annu Rev Biochem, 61, $1175-1212$.

Bogrnhagen, Daniel F. 1999. DNA REPAIR'99 Repair of mtDNA in Vertebrates. Am. J. Hum. Genet. 64, 1276-1281.

Muladno. 2010. Teknologi Rekayasa Genetika. Edisi Kedua. Bogor. IPB Press.

Innis, M.A., Gelfan, D.H. (1990), Optimation of PCRs, PCR protocols :a guide to Methods and Aplications, Academic Press, Inc, California, 3-12.

Zyskind, J. W. and S. I. Bemstain. 1992. Recombinant DNA Manual. Academic Press., Inc. California.

Sambrook, J., Fritsc, E.F., and Maniatis, T., (1989), Molecular Cloning, A Laboratory Manual 2nd, Cold Spring Harbor Laboratory Press, New York.

Puspitasari, Dea.(2007). Urutan Nukleotida Daerah HVSI DNA Mitokondria Manusia Poli-C. Skripsi Program Studi ITB Bandung: Tidak diterbitkan. 
Qiagen.(2006).Genomic DNA Purification. [Online]. Tersedia : http: //www. qiagen.com /literature brochurs /index. [5 Oktober 2015].

Ratnayani, K., et al (2007). "Analisis Variasi Nukleotida Daerah D-Loop DNA Mitokondria Pada Satu Individu Suku Bali Normal “ Jurnal Kimia 7-14 